Zhengwei Huang ${ }^{1}$, Xueke Pei' ${ }^{1}$ Jing Xi'2, Bestoon Othman³ ${ }^{3}$ Sher Ali', Ling Lin ${ }^{4}$

${ }^{1}$ China Three Gorges University, College of Economics and Management, 443000 Yichang, China P. R.

2 China Three Gorges University, College of International Communications, 443000 Yichang, China P. R.

${ }^{3}$ Erbil Polytechnic University, Koya Technical Institute, Department of Business Administration, 44001 Erbil, Kurdistan, Iraq

${ }^{4}$ China Three Gorges University, School of Foreign Languages, 443000 Yichang, China P. R.

\title{
The Influence of Consumers' Perception on Perceived Value and Purchase Intention with respect to Regional Products Based on a C-A-B Model
}

vpliv dojemanja potrošnika na zaznano vrednost in na namero nakupa regionalnih izdelkov - na podlagi modela $C-A-B$

Original Scientific Article/lzvirni znanstveni članek

Received/Prispelo 05-2019• Accepted/Sprejeto 09-2019

\begin{abstract}
Consumer interest has been moving progressively toward local regional clothing products in many countries. Hence, this study endeavours to examine consumer perception and purchase intention, and their interrelationship in the context of regional clothing products. A framework built on the basis of a C-A-B model and a questionnaire were used to collect data through online and offline sources. The proposed model was empirically evaluated based on 407 respondents. The results reveal that both consumer perception and the perceived value of regional clothing products have a positive influence on consumers' purchase intentions, while perceived value also plays a role in the purchase process. Nevertheless, word-of-mouth plays a predominant role among other influential factors of consumer perception, such as uniqueness and regionality. Keywords: regional clothing products, consumers' perception, C-A-B model, purchase intention
\end{abstract}

Izvleček

$\checkmark$ številnih državah je bilo opaziti, da se zanimanje potrošnikov za izdelke iz blaga iz njihove regije postopoma povečuje. Zato si v tej študiji avtorji prizadevajo preveriti zaznavanje in namero potrošnikov in njihovo povezavo vokviru regionalnih oblačil. Za zbiranje podatkov so bili uporabljeni ogrodje, ki temelji na modelu C-A-B, ter vprašalniki po spletu in brez povezave. Predlagani model je bil empirično ovrednoten, podatke pa je zbiralo 407 anketirancev. Rezultat razkriva, da tako zaznavanje potrošnikov kot zaznana vrednost regionalnih oblačilnih izdelkov pozitivno vplivata na kupčeve namene, medtem ko zaznana vrednost posreduje pri nakupu. Kljub temu ima ustno sporočilo prevladujočo vlogo med drugimi vplivnimi dejavniki dojemanja potrošnikov, kot sta edinstvenost in regionalnost. Ključne besede: regionalni oblačilni izdelki, dojemanje potrošnikov, model C-A-B, namen nakupa

\section{Introduction}

The prospering economy and the growing desire for regional clothing products have attracted growing interest in recent years. The online revolution also

Corresponding author/Korespondenčni avtor:

Jing Xi

E-mail: geanxi@ctgu.edu.cn contributes increasingly to the accessibility of regional clothing products, which helps lift geographical limits on regional clothing products to make them more visible to consumers around the country $[1,2]$. The improving reputation of regional clothing

Tekstilec, 2019, 62(3), 219-228

DOI: 10.14502/Tekstilec2019.62.219-228 
products has also been strengthened by more convenient modes of transportation and the telecommunications network [3-6]. It has thus become essential to have a better understanding of how the perception of the value of regional clothing products influence consumers' purchase intentions.

Every city or region across the country has its own regional clothing products rooted in the regional environment. Whatever the categorisation of those regional clothing products may be, they are distinguished by their uniqueness $[7,8]$. Numerous researchers define regional clothing products in many different contexts as they relate to products manufactured locally with special characteristics in terms of style or artisanship [4, 9-11]. In China, however, regional clothing products comprise the Guangzhou Baima Costume Market, Shenzhen Yiwu Smallware Wholesale Mansion, Ladies Market, Huangyuan Wholesale Garment Market-Jardine's Crescent Market and many more. In a word, regional clothing products have recognisable characteristics in terms of locality, nationality, unique processing technologies, unique and innovative handling techniques, historical preservation and a rich cultural legacy [12-14].

Most recent studies focus on packaging design and brand marketing, and neglect the uniqueness of regional clothing products [15-19]. It therefore makes sense to construct a framework based on the cognition-affect-behaviour (C-A-B) model. The C-A-B model is an information-processing approach, where the purchase decision and brand choice are the key outcomes. This interpretation of responses is closely aligned with, but expands on, the behaviour component of the C-A-B model, which focuses on brand choice or purchase decisions to study the factors that affect consumers' purchase intentions and a company's marketing strategy in an effort to promote the relationship between companies and consumers, and boost regional clothing products [20]. This study entails two contributions: (1) an analysis of the uniqueness of regional clothing products and how word-of-mouth influences perceived value and consumers' purchase intentions; and (2) the application of the C-A-B model to explore factors that influence consumers' purchase intentions, with the aim of expanding the applicability of the C-A-B model.

Holbrook [21] proposes an innovative model to describe consumer's behaviour, a process that ranges from perception to behaviour. Consumers are thought to be target-oriented problem solvers who search for product information, weigh all available evidence and then make a purchase decision after several rounds of reconsideration. Degirmenci [22] believes that consumers are logical thinkers whose aim is to select the best available products from different options. Hirschman [23] proposed that cognition in the C-A-B model is only one component of the psychological factors that affect consumers' behaviour. Cognition embodies concepts, ideas or perceptions that derive from interaction with products (merchandise, service, consumption environment, etc.) and the process of handling less important information (advertisement, reviews from friends, blogs, online merchandise reviews, etc.) [24]. However, as part of the information-processing based C-A-B model, effect differs from emotion. Effect is defined as a favourable disposition toward a stimulus that leads to a relative preference for stimulus from a group of options. Blackwell et al. [25] and Andrei et al. [17] proposed a multi-dimensional construct for behavioural intentions composed of word-of-mouth, price insensitivity, purchase intentions, and complaint behaviour toward a retailer. The approach response has also been operationalised as a measure of satisfaction with the shopping experience and brand loyalty.

\section{Research hypothesis and model building \\ 2.1 Uniqueness}

Regional clothing products are unique, which might be attributable to a specific natural environment, history, a special processing technique or art. Tian [26] and Liu [27] find that product uniqueness relates to the perceived attributes consumers feel that can distinguish a product from generic merchandise. Eisend [28] and Jang [29] find that highlighting the specific uniqueness of a certain product could reduce the risk associated with the launch of a new product on the market. For this reason, emphasising product uniqueness becomes an inseparable part of building a brand asset. Product uniqueness is a vital component of a brand asset, which presents uniqueness by virtue of an exclusively possessed attribute or excellence. When consumers have certain demands, distinctive products easily stand out. By and large, a product brand is also useful in practical terms. Markets test a product category, and con- 
sumers' loyalty and trust might derive from such a test. Irmak [30], as an advocate of cognition theory, claims that augmenting product uniqueness will promote consumers' purchase intentions. This means that consumers have a distinctive purchase motivation to separate themselves from ordinary consumers through purchase choices. Thus, uniqueness in regional clothing products will influence consumers' purchase intentions. Wu [31] finds that product uniqueness becomes a predominant factor in determining what motivates consumers to make purchase decisions. Barat [32] asserts that the scarcity perceived by consumers will influence perceived uniqueness, which in turn is very influential in purchase decisions. The uniqueness of regional clothing products can be attributed to a specific environment, meaning product scarcity is the result of the inability to mass produce a product or products. We thus hypothesise that uniqueness and scarcity will influence consumers' trust in product quality and have a positive influence on a brand.

$\mathrm{H} 1$ : The uniqueness of regional clothing products has a positive influences on consumers' perceived value.

$\mathrm{H} 2$ : The uniqueness of regional clothing products has a positive influences on consumers' purchase intentions.

\subsection{Regionality}

Regionality refers to the features that distinguish a product from others, and can be attributed to the distinctiveness of a certain region's specific natural or cultural environment. Nallaperuma [33] argues that regionality is found to have a special appeal to consumer in marketing regional clothing products. When consumers are insufficiently familiar with products, Ehmke [34] finds that they are unable to make informed decisions about such products and are prone to make inferences about quality in terms of a manufacturing region's image. For regional clothing products, natural and geological conditions are a decisive factor in the perceived quality and taste of manufactured products. Terano et al. [35] find that regionality might improve product image and thus influence consumers' purchase decisions: the better a region's image is, the better consumer reviews tend to be, and that all beliefs regarding a product will influence the overall opinion about that product. Knight [36] and Bosona [37] determined that consumers have different attitudes regarding regional clothing products from various regions, Bloemer [38] determined that, depending on perceptions brought about by regional attributes, consumers' ultimate purchase intentions are influenced by perceived values. For this reason, regional cultural products must take regionality into consideration to help consumers distinguish regional clothing products from others, and to link consumers with other relevant regional cultural images. Cultural images are, to a great extent, intangible or virtual, which thus literally mirrors the in-depth psychological demand of consumers.

H3: Regionality has a positive influence on consumers' perceived value.

H4: Regionality has a positive influence on consumers' purchase intentions.

\subsection{Word-of-mouth}

In the 1960s, Arndt [39] pointed out that word-ofmouth (interpersonal and non-commercial verbal or non-verbal communication about certain products) could promote the marketing of products or services. In marketing, promotion refers to any type of marketing communication used to inform or persuade target audiences of the relative merits of a product, service, brand or issue. The aim of promotion is to increase awareness, create interest, generate sales or create brand loyalty.

In the social network of consumers, Anderson [40] finds that word-of-mouth carries verbal information and has a major influence on word-of-mouth communication because consumers are not only pioneers in sharing their experiences regarding products or services, but also serve as administrators of information communication. Due to asymmetric information, potential consumers' cognition about products could be enhanced by word-of-mouth through the effort of those pioneering consumers whose behaviour reduces that asymmetry. Chevalier [41] finds that this increases consumers' perceived value and improves product marketing. Gupta [42] finds that word-of-mouth is the most powerful motivating factor in consumers' purchase intention among marketing approaches. Word-ofmouth reduces consumers' risk and uncertainty in making purchase decisions. Lee [43] finds that over half of US consumers asked friends or relatives for advice when purchasing durable consumer goods, while more than one third of consumers consulted with family members about the durable consumer 
goods of a certain brand. The power of word-ofmouth is that much more important in the purchase of regional clothing products or services.

H5: Word-of-mouth has a positive influence on consumers' perceived value

H6: Word-of-mouth has a positive influence on consumers' purchase intentions.

\subsection{Perceived value and purchase intentions}

There is a great deal of literature about perceived value and purchase intentions, which justifies the choice to focus our study on purchase intentions. Tam [44] finds that perceived value is the primary factor influencing consumers' purchase intentions. Zeithaml [45] concludes from abundant research that the better consumers' perception about a product or service is, the more value they feel, which in turn enhances consumers' purchase intentions. Hsu [46] notes that consumer's satisfaction is important, but that perceived value is the ultimate trigger in consumers' purchase behaviour. El-Adly [47] notes that purchase intention is determined by perceived values. In his research, Huijgens [48] points out that consumers' purchase behaviour is motivated more by perceived value than consumer satisfaction. In a word, contemporary research has confirmed that consumers' purchase intentions are decided by the perceived value of perceived benefits and potential costs. From the point of view of consumers, the more perceived benefits there are, the higher perceived value is, and the higher perceived value is, the stronger the purchase intention will be.

H7: Perceived value has a positive influence on consumers' purchase intentions.

\subsection{Model building}

Based on all proposed hypothesis, a conceptual model involving cognition, perceived value and purchase intention was constructed, as shown in Figure 1.

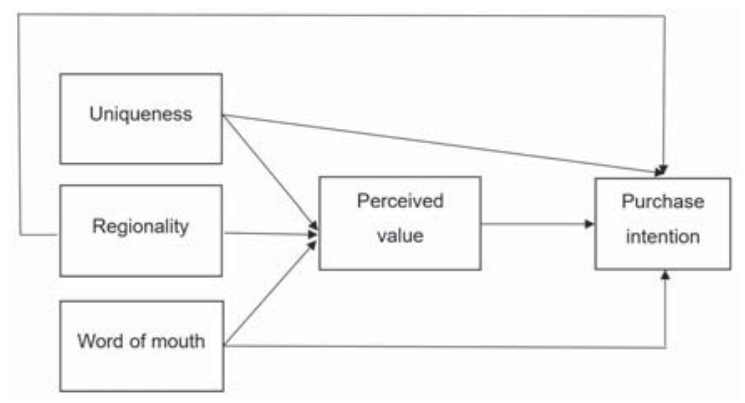

Figure 1: Model of conceptual framework

\subsection{Research design}

\subsubsection{Questionnaire}

In order to achieve an accurate measurement of regionality $(\mathrm{R})$, uniqueness $(\mathrm{U})$, word-of-mouth (WOM), perceived value (PV) and purchase intention (PI), this study developed and used a scale in which items were tested, refined and purified. The final scale was developed in the form of a Likert five-point scale, where 1 means 'strongly disagree' and 5 means 'strongly agree', using 16 refined items. Regionality, a key variable, is measured using a scale developed by Nallaperuma [33]. Word-of-mouth is measured using a scale developed by Arndt [39] and perceived value is measured based on a modified scale developed by Zeithaml [45]. Purchase intention is measured using a modified scale proposed by Tam [44]. This study used SPSS 23 and SmartPLS 3.0 software to process and analyse data.

\subsubsection{Data collection}

The population of our study comprises self-earning and self-spending people. This study follows a quantitative method, while a combination of online and offline methods at retail outlets that sell regional clothing products was used to obtain data from customers who had bought regional clothing products. Data was collected from customers in the period April to June 2018. Data were collected in the Hubei province of China. A total of 407 responses to our questionnaire were received. Of that number, 375 were considered correct and used in further analysis. After eliminating unqualified questionnaires, the effectiveness rate was $92 \%$ of the total. In terms of respondents, $45.78 \%$ were male and $54.22 \%$ were female. Those 18 years and younger accounted for $10.42 \%$ of respondents, those $18-30$ years age for $51.87 \%$, those $31-40$ years of age for $24.74 \%$, and those $41-50$ years of age for $12.97 \%$. A total of $5.32 \%$ of respondents' per capita household income was below $€ 125$ (RMB), 35.57\% of respondents' per capita household income ranged from $€ 125-379$ (RMB), $41.94 \%$ of respondents' per capita household ranged from €380-570 (RMB), and $17.27 \%$ of respondents' per capita household income was higher than $€ 570$. A total of $4.63 \%$ of respondents finished primary school, $11.35 \%$ of respondents finished middle school, 26.32\% of respondents finished high school or three-year tertiary education, and $57.70 \%$ of respondents finished higher tertiary education. 
Table 1: Measurement items and content

\begin{tabular}{|c|c|c|}
\hline Variable & $\begin{array}{l}\text { Measu- } \\
\text { rement }\end{array}$ & Content \\
\hline \multirow{3}{*}{$\begin{array}{l}\text { Uniqueness } \\
\text { (U) }\end{array}$} & U1 & Regional clothing products are different from other similar products \\
\hline & $\mathrm{U} 2$ & Regional clothing products stand out from other similar products \\
\hline & U3 & Regional clothing products are unique compared with other similar products \\
\hline \multirow[t]{3}{*}{$\begin{array}{l}\text { Regionality } \\
\text { (R) }\end{array}$} & R1 & $\begin{array}{l}\text { I can identity the majority of familiar regional clothing products with the } \\
\text { region to which they belong }\end{array}$ \\
\hline & $\mathrm{R} 2$ & $\begin{array}{l}\text { I can place regional clothing products I am are familiar with in the region to } \\
\text { which they belong }\end{array}$ \\
\hline & R3 & Regional clothing products are judged by their location \\
\hline \multirow{3}{*}{$\begin{array}{l}\text { Word of } \\
\text { mouth } \\
\text { (WOM) }\end{array}$} & WOM1 & I tend agree with people familiar with purchasing regional clothing products \\
\hline & WOM2 & I would recommend regional clothing products to others \\
\hline & WOM3 & $\begin{array}{l}\text { I would recommend regional clothing products to those who ask for } \\
\text { purchasing advice }\end{array}$ \\
\hline \multirow{4}{*}{$\begin{array}{l}\text { Perceived } \\
\text { value (PV) }\end{array}$} & PV1 & I like regional clothing products very much \\
\hline & PV2 & I think a specific local product is superior to other products of the same type \\
\hline & PV3 & I think a specific local product is of superior quality at a reasonable price \\
\hline & PV4 & I think regional clothing products are of good quality \\
\hline \multirow{3}{*}{$\begin{array}{l}\text { Purchase } \\
\text { intention } \\
(\mathrm{PI})\end{array}$} & PI1 & Regional clothing products are highly attractive to me \\
\hline & PI2 & I think it pays to purchase regional clothing products \\
\hline & PI3 & I would recommend regional clothing products to others \\
\hline
\end{tabular}

\section{Results}

\subsection{Reliability and validity test}

Bartlett's test of sphericity and the Kaiser-MeyerOlkin (KMO) test preceded the principal component analysis (PCA) to test if the KMO value was relevant for the PCA that followed. The results showed that the value of KMO was 0.824 and $\mathrm{KMO}$ test significance was 0.001 , meaning that the PCA was suitable. After rotating the factor loading matrix, five factors were extracted, while the percent variance was $69.499 \%$. As a rule, the AVE value, as a base criterion, should be more than 0.5 , while the total variance explained should be higher than the base standard of 50\%, and factor loading should be higher than 0.5 . The results using SmartPLS 3.0 software showed that Cronbach's alpha values for uniqueness, regionality, word-ofmouth, perceived value and consumer purchase intention were $0.795,0.808,0.814,0.741$ and 0.837 respectively. Cronbach's alpha coefficient was utilised in this study, together with composite reliability values to examine the inter-item consistency of the measurement of items. The Cronbach's alpha and composite reliability (CR) values should be higher than 0.70 [49]. With respect to Cronbach's alpha and composite reliability value, Koonce and Kelly [50] pointed out that a reliability value in excess of 0.9 is regarded as excellent, a value higher than 0.8 is good, a value higher than 0.7 is adequate, a value higher than 0.6 is doubtful and a value lower than 0.5 is substandard. This demonstrated the good internal consistency of questionnaire items. Thus, items in this scale were deemed highly reliable.

In terms of discriminative validity, if the square root of AVE for every factor is higher than coefficient of the factor to other factors, this means that the test items in this scale demonstrated good discriminative validity. Table 3 shows that values in diagonal lines are higher than the values in the same volume, which demonstrates good discriminant validity. 
Table 2: Reliability and validity analysis

\begin{tabular}{|c|c|c|c|c|c|}
\hline Variable & Measurement & Standard load & $\mathrm{AVE}^{\mathrm{a})}$ & $\mathrm{CR}^{\mathrm{b})}$ & Cronbach's alpha \\
\hline \multirow{3}{*}{$\begin{array}{l}\text { Uniqueness } \\
\text { (U) }\end{array}$} & U1 & 0.762 & \multirow[t]{3}{*}{0.711} & \multirow[t]{3}{*}{0.880} & \multirow[t]{3}{*}{0.795} \\
\hline & $\mathrm{U} 2$ & 0.873 & & & \\
\hline & U3 & 0.783 & & & \\
\hline \multirow{3}{*}{$\begin{array}{l}\text { Regionality } \\
\text { (R) }\end{array}$} & $\mathrm{R} 1$ & 0.802 & \multirow[t]{3}{*}{0.722} & \multirow[t]{3}{*}{0.886} & \multirow[t]{3}{*}{0.808} \\
\hline & R2 & 0.840 & & & \\
\hline & R3 & 0.797 & & & \\
\hline \multirow{3}{*}{$\begin{array}{l}\text { Word-of- } \\
\text { mouth } \\
\text { (WOM) }\end{array}$} & WOM1 & 0.838 & \multirow[t]{3}{*}{0.728} & \multirow[t]{3}{*}{0.889} & \multirow[t]{3}{*}{0.814} \\
\hline & WOM2 & 0.840 & & & \\
\hline & WOM3 & 0.730 & & & \\
\hline \multirow{4}{*}{$\begin{array}{l}\text { Perceived } \\
\text { value (PV) }\end{array}$} & PV1 & 0.690 & \multirow[t]{4}{*}{0.560} & \multirow[t]{4}{*}{0.836} & \multirow[t]{4}{*}{0.741} \\
\hline & PV2 & 0.828 & & & \\
\hline & PV3 & 0.709 & & & \\
\hline & PV4 & 0.642 & & & \\
\hline \multirow{3}{*}{$\begin{array}{l}\text { Purchase } \\
\text { intention (PI) }\end{array}$} & PI1 & 0.806 & \multirow[t]{3}{*}{0.754} & \multirow[t]{3}{*}{0.902} & \multirow[t]{3}{*}{0.837} \\
\hline & PI2 & 0.826 & & & \\
\hline & PI3 & 0.807 & & & \\
\hline
\end{tabular}

a) Average variance extracted; b) Composite reliability.

Table 3: Discriminant validity

\begin{tabular}{|l|c|c|c|c|c|}
\hline $\begin{array}{c}\text { Con- } \\
\text { struct }\end{array}$ & $\mathrm{U}^{\mathrm{a})}$ & $\mathrm{R}^{\mathrm{b})}$ & $\mathrm{WOM}^{\mathrm{c})}$ & $\mathrm{PV}^{\mathrm{d})}$ & $\mathrm{PI}^{\mathrm{e})}$ \\
\hline $\mathrm{U}$ & 0.853 & & & & \\
\hline $\mathrm{R}$ & 0.308 & 0.849 & & & \\
\hline WOM & 0.410 & 0.277 & 0.748 & & \\
\hline PV & 0.317 & 0.388 & 0.286 & 0.843 & \\
\hline PI & 0.451 & 0.346 & 0.391 & 0.346 & 0.868 \\
\hline
\end{tabular}

a) Uniqueness; ${ }^{\text {b) }}$ Regionality; ${ }^{c)}$ Word-of-mouth;

d) Perceived value; e) Purchase intention.

\subsection{Hypothesis test}

This SEM iteration operation using Smart PLS 3.0 software showed that iteration convergence occurs after seven hypothesis operations. It also showed the obtained significance and path coefficient values illustrated in Table 4 and Figure 2.

The first hypothesis is uniqueness (U), which has a positive influence on perceived value (PV), while literature usually supports this relationship. Similarly, the relationship between these constructs was also deemed significant $(\beta=0.144, \mathrm{t}=2.945$, $\mathrm{p}<0.005)$ in the context of clothing products. The second hypothesis of uniqueness (U) had a positive and significant impact on purchase intention (PI). The findings showed that the path coefficient from U to PI was statistically significant with a very strong standardised estimation, as well as a high $\mathrm{t}$-value of more than $2.58(\mathrm{p}<0.001)$. The coefficient between regionality $(\mathrm{R})$ and perceived value $(\mathrm{PV})$ was $(\beta=0.124, \mathrm{t}=2.345, \mathrm{p}<0.023)$. That value indicated that regionality $(\mathrm{R})$ has a positive influence on perceived value (PV). The fourth hypothesis of regionality $(\mathrm{R})$ had a positive influence on purchase intention (PI). The results obtained from Smart PLS software indicated that there was a significant connotation between regionality $(\mathrm{R})$ and purchase intention $(\mathrm{PI})(\mathrm{P}<0.005)$. The coefficient between word-of-mouth (WOM) and perceived value $(\mathrm{PV})$ was $(\beta=0.329, \mathrm{t}=6.755, \mathrm{p}<0.000)$. That value demonstrated that word-of-mouth (WOM) has a positive influence on perceived value (PV). The coefficient between word-of-mouth (WOM) and purchase intention (PI) was $(\beta=0.279, \mathrm{t}=5.030$, $\mathrm{p}<0.000)$. That value showed that regional clothing products have a positive influence on purchase intention. The last hypothesis (H7) postulates a significant relationship between perceived value 
(PV) and purchase intention (PI), where past studies typically support this relationship. Similarly, the relationship between these constructs was also found to be significant $(\beta=0.194, \mathrm{t}=3.735, \mathrm{p}<0.000)$ in the context of clothing products. The value showed that perceived value $(\mathrm{PV})$ has a positive influence on purchase intention (PI).

This study finds that cognition of regional clothing products influences perceived value and purchase intention. Based on the data we obtained, we built a model to study cognition impact on purchase intention in terms of the C-A-B model. The empirical study showed that uniqueness, regionality and word-of-mouth have a significant influence on perceived value and purchase intention, which illustrates the cognition level of consumers in their purchase decision behaviour. This conclusion is in line with studies conducted by other researchers. It could be explained by the fact that the more consumers know about regional clothing prod-

Table 4: Summary of the direct results of hypotheses testing

\begin{tabular}{|c|l|c|c|c|}
\hline $\begin{array}{c}\text { Hypo- } \\
\text { theses }\end{array}$ & \multicolumn{1}{|c|}{ Path } & $\beta$ & t-value & p-value \\
\hline $\mathrm{H} 1$ & $\left.\mathrm{U}^{\mathrm{a})} \rightarrow \mathrm{PV}^{\mathrm{b}}\right)$ & 0.144 & 2.945 & 0.005 \\
\hline $\mathrm{H} 2$ & $\left.\mathrm{U} \rightarrow \mathrm{PI}^{\mathrm{c}}\right)$ & 0.134 & 3.212 & 0.001 \\
\hline $\mathrm{H} 3$ & $\mathrm{R}^{\mathrm{d})} \rightarrow \mathrm{PV}$ & 0.124 & 2.345 & 0.023 \\
\hline $\mathrm{H} 4$ & $\mathrm{R} \rightarrow \mathrm{PI}$ & 0.150 & 2.762 & 0.005 \\
\hline $\mathrm{H} 5$ & $\begin{array}{l}\left.\mathrm{WOM}^{\mathrm{e}}\right) \rightarrow \\
\mathrm{PV}\end{array}$ & 0.329 & 6.755 & 0.000 \\
\hline $\mathrm{H} 6$ & $\begin{array}{l}\mathrm{WOM} \rightarrow \\
\mathrm{PI}\end{array}$ & 0.279 & 5.030 & 0.000 \\
\hline $\mathrm{H} 7$ & $\mathrm{PV} \rightarrow \mathrm{PI}$ & 0.194 & 3.735 & 0.000 \\
\hline
\end{tabular}

a) Uniqueness; ${ }^{\text {b) }}$ Perceived value; ${ }^{\text {c) }}$ Purchase intention;

d) Regionality; ${ }^{\text {e) Word-of-mouth }}$

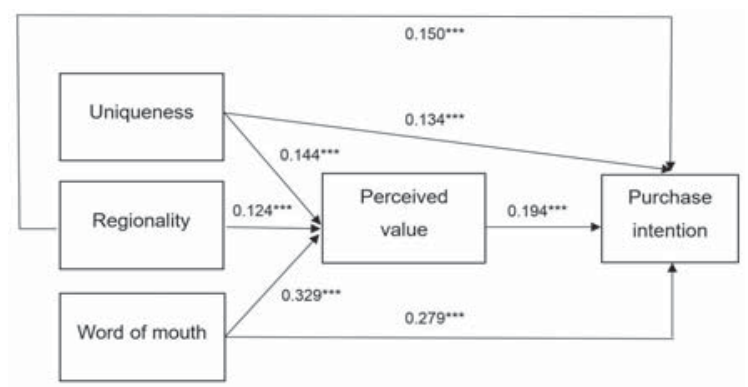

Figure 2: PLS algorithm results ucts, the more they will realise the advantages of regional clothing products, and the stronger their purchase intentions might be.

\section{Conclusion}

The marketing strategy associated with regional clothing products should focus more on uniqueness to reinforce consumers' purchase intensions. Brand names could deliver the unique value of regional clothing products to consumers, which in turn can help to increase their worth and identity. Regional clothing product companies must improve overall product image through an innovative packaging strategy to reinforce the uniqueness of regional clothing products. It should be emphasised that overall product image, in particular visual identity, name and packaging, are fundamental for building a brand image, which in will turn help consumers to distinguish a product from others and also support companies in the establishment of their own unique image.

Consumers' perceived value for regional clothing products can be greatly improved by enhancing a regional clothing product design. Regional clothing products could reflect the local culture, which appeals to a growing number of consumers. It should to be pointed out that regional clothing products could deliver a unique culture that endorses regional properties. From the consumers perspective, consumers purchase not only the product itself; cultural value also leads to increased consumption. Regional clothing products could explore regional and historical culture based on geographical and cultural conditions in order to find a niche that could satisfy both consumers and companies.

Word-of-mouth can be used as a marketing strategy to attract consumers. The media can contribute positively by helping to create an agreeable image about regional clothing products through word-of-mouth publicity and thus induce positive comments about products. Those strategies can greatly enhance consumers' cognition about regional clothing products and enhance their purchase intentions. However, TV ads, search engine rankings, public advertisement boards, tourist spot marketing, trade fairs and sales exhibitions are useful tools to promote the image of regional clothing products. To make this approach more operational, the promotion of local cultural 
customs and geological features should be encouraged. The Wuhan Municipal government serves as a very successful example in this respect by promoting Wuhan clothing and the Xinyang clothing culture through marketing activities. Another good example comes from Hubei, which promotes hundreds of designed artworks for different countries. All designs have been positively accepted by the market.

One considerable limitation to this study is the fact that there is very limited literature available with indepth discussions relating to this target area. In most previous studies, the consumption pattern is not stated as a variable in constructing any model. Although, in theory, correlation with purchase intention precedes purchase behaviour, we should still consider the fact that behaviour might counteract attitude. Thus, for future research, it is strongly recommended that the behaviour factor be included in model construction to gain more insightful understanding. The small amount of data might also influence the validity of model construction, while point-to-surface data analysis is still disputable. It is thus quite difficult to propose operational strategies with great pertinence. Lastly, this empirical and hypothetical study only constructed a framework of consumers' purchase intentions, which calls for the inclusion of additional variables to build innovative models. We therefore think that future research could focus on including consumers' emotions and attitudes in a model, and introduce additional medium and moderating variables to better explain consumers' behaviour.

\section{Acknowledgements}

This paper was written under a grant from the $\mathrm{Na}$ tional Natural Science Foundation of China (No.71471102).

\section{References}

1. GOLD, Jeff, THORPE, Richard, MUMFORD, Alan. Leadership and management development. $5^{\text {th }}$ edition. London : CIPD, 2010.

2. GALLARZA, Martina G. GIL-SAURA, Irene, HOLBROOK, Morris B. The value of value: Further excursions on the meaning and role of customer value. Journal of Consumer Behaviour, 2011, 10(4), 179-191, doi: 10.1002/cb.328.

3. McCLUSKEY, Annie, LOVARINI, Meryl. Providing education on evidence-based practice improved knowledge but did not change behaviour: a before and after study. BMC Medical Education, 2005, 5(40), 1-12, doi: 10.1186/1472-69205-40.

4. FRANK, B, ENKAWA, T. Economic influences on customer satisfaction: variation by product function. In 2008 IEEE International Conference on Industrial Engineering and Engineering $\mathrm{Ma}$ nagement, 2008, pp. 203-207, doi: 10.1109/ IEEM.2008.4737860.

5. KOTLER, Philip, KELLER, Kevin Lane. A framework for marketing management. Upper Saddle River (N.J.) : Pearson/Prentice Hall, 2011.

6. EASTERLIN, Richard A., ANGELESCU, Laura. Modern economic growth and quality of life: cross-sectional and time series evidence. In Handbook of Social Indicators and Quality of Life Research. Edited by Kenneth C. Land, Alex C. Michalos, M. Joseph Sirgy. Springer Netherlands, 2012, pp. 113-136, doi: 10.1007/978-94-007-2421-1_6.

7. Van ITTERSUM, Koert, CANDEL, Math J. J., MEULENBERG, Matthew T. G. The influence of the image of a product's region of origin on product evaluation. Journal of Business Research, 2003, 56(3), 215-226, doi: 10.1016/S01482963(01)00223-5.

8. FROCHOT, Isabelle. An analysis of regional positioning and its associated food images in French tourism regional brochures. Journal of Travel and Tourism Marketing, 2003, 14(3-4), 77-96, doi: 10.1300/J073v14n03_05.

9. HAN, C. Min. Country image: halo or summary construct? Journal of Marketing Research, 1989, 26(2), 222-229 doi: 10.2307/3172608.

10. HENCHION, Maeve, MCINTYRE, Bridin. The use of regional imagery in the marketing of quality products and services. Irish Marketing Review, 2000, 13(2), 19.

11. RAINER, Hass. The Austrian country market: a European case study on marketing regional products and services in a cyber mall. Journal of Business Research, 2002, 55(8), 637-646, doi: 10.1016/S0148-2963(00)00204-6.

12. BRUWER, Johan, JOHNSON, Ray. Place-based marketing and regional branding strategy perspectives in the California wine industry. Journal of Consumer Marketing, 2010, 27(1), 5-16, doi: 10.1108/07363761011012903.

13. Van ITTERSUM, Koert, MEULENBERG, Matthew, T. G. Consumers' appreciation of regional certification labels: a Pan-European study. Journal 
of Agricultural Economics, 2007, 58(1), 1-23, doi: 10.1111/j.1477-9552.2007.00080.x.

14. McCANN, Jane, HURFORD, Richard, MARTIN, Adam. A design process for the development of innovative smart clothing that addresses end-user needs from technical, functional, aesthetic and cultural view points. In Ninth IEEE International Symposium on Wearable Computers (ISWC'05), 2005, doi: 10.1109/ISWC.2005.3.

15. KLIMCHUK, Marianne Rosner, KRASOVEC, Sandra A. Packaging design: Successful product branding from concept to shelf. Second edition. Hoboken (New Jersey) : J. Willey \& Sons, 2013.

16. SHAH, Sabeehullah, AHMAD, Adnan, AHMAD, Nawaz. Role of packaging in consumer buying behavior. International Review of Basic and Applied Sciences, 2013, 1(2), 35-41.

17. ANDREI, Gabriela Andreia, ZAIT, Adriana, VĂTĂMĂNESCU, Elena-Mădălina, PÎNZARU, Florina. Word-of-mouth generation and brand communication strategy: Findings from an experimental study explored with PLS-SEM. Industrial Management and Data Systems, 2017, 117(3), 478-495, doi: 10.1108/imds-11-20150487 10.1108/imds-11-2015-0487.

18. FLEITH de MEDEIROS, Janine, DUARTE RIBEIRO, Jose Luis, Nogueira Cortimiglia, Marcelo. Success factors for environmentally sustainable product innovation: A systematic literature review. Journal of Cleaner Production, 2015, 65(July), 76-86, doi: 10.1016/j.jclepro.2013.08.035.

19. TULLY, Stephanie M., WINER, Russell, S. The role of the beneficiary in willingness to pay for socially responsible products: A meta-analysis. Journal of Retailing, 2014, 90(2), 255-274, doi: 10.1016/j.jretai.2014.03.004.

20. FIORE, Ann Marie, JIHYUN Kim. An integrative framework capturing experiential and utilitarian shopping experience. International Journal of Retail \& Distribution Management, 2007, 35(6), 421-442, doi: 10.1108/09590550710750313.

21. HOLBROOK, Morris B. Emotions in the consumption experience: Toward a new model of consumer behavior. In The role of affect in consumer behavior: Emerging theories and applications. Edited by Robert A. Peterson, Wayne D. Hoyer and William Raft Wilson. 1986, Lexington : Lexington Books, pp. 17-52.

22. DEGIRMENCI, Kenan, BREITNER, Michael H. Consumer purchase intentions for electric vehicles: Is green more important than price and range? Transportation Research Part D: Transport and Environment, 2017, 51(March), 250-260, doi: 10.1016/j.trd.2017.01.001.

23. HIRSCHMAN, Albert O. Rival interpretations of market society: Civilizing, Destructive, or Feeble? Journal of Economic Literature, 1982, 20(4), 1463-1484.

24. FORGAS, Joseph P. Mood effects on cognition: Affective influences on the content and process of information processing and behavior. In Emotions and affect in human factors and human-computer interaction. Edited by Jeon Myounghoon. London : Elsevier, 2017, pp. 89-122.

25. BLACKWELL, Roger D., MINIARD, Paul W., ENGEL, James F. Consumer behavior. $9^{\text {th }}$ edition. London : Harcourt College, 2001.

26. TIAN, Kelly Tepper, BEARDEN, William O., HUNTER, Gary L. Consumers' need for uniqueness: scale development and validation. Journal of Consumer Research, 2001, 28(1), 50-66, doi: 10.1086/321947.

27. LIU, Jianxin, LI, Dongjin. A paratactic and multiple mediating mechanism on the effect of product scarcity appeal on consumer' willingness to purchase. Nankai Business Review, 2017, 20(4), 4-15.

28. EISEND, Martin. Explaining the impact of scarcity appeals in advertising: The mediating role of perceptions of susceptibility. Journal of Advertising, 2008, 37(3), 33-40, doi: 10.2753/ joa0091-3367370303.

29. JANG, Wonseok Eric, KO, Yong Jae, MORRIS, Jon D, CHANG, Yonghwan. Scarcity message effects on consumption behavior: limited edition product considerations. Psychology and Marketing, 2015, 32(10), 989-1001, doi: 10.1002/mar.20836.

30. IRMAK, Caglar, VALLEN, Beth, SANKAR, Sen. You like what I like, but I don't like what you like: Uniqueness motivations in product preferences. Journal of Consumer Research, 2010, 37(3), 443-455, doi: 10.1086/653139.

31. WU, Wann-Yih, LU, Hsiao-Yun, WU, Ying-Yin, FU, Chen-Su. The effects of product scarcity and consumers' need for uniqueness on purchase intention. International Journal of Consumer Studies, 2012, 36(3), 263-274, doi: 10.1111/ j.1470-6431.2011.01000.x.

32. BARAT, Somjit, YE, Lilly. Effects of coupons on consumer purchase behavior: A meta-analysis. 
In Developments in marketing science: Proceedings of the Academy of Marketing Science. Springer International Publishing, 2015, p. 30, doi: 10.1007/978-3-319-11779-9_15.

33. NALLAPERUMA, Kaushalya, BANDYOPADHYAY, Argho, LOCKSHIN, Larry. A comparative analysis of experts' and consumers' perceptions of regionality in Australian wine purchase decisions. Journal of Wine Research, 2017, 28(4), 194-215, doi: 10.1080/09571264.2017.1360261.

34. EHMKE, Mariah D., LUSK, Jayson L., TYNER, Wallace. Measuring the relative importance of preferences for country of origin in China, France, Niger, and the United States. Agricultural Economics, 2010, 38(3), 277-285, doi: 10. 1111/j.1574-0862.2008.00299.x.

35. TERANO, Rika, ZAINALABIDIN, Mohamed, REZAI, Golnaz, HANUM, Zakiah. Preference for locally grown or imported fruit among the millennial generation in Johor, Malaysia. Journal of Food Products Marketing, 2016, 22(8), 1-14, doi: 10.1080/10454446.2015.1072868.

36. KNIGHT, Gary A., CALANTONE, Roger J. A flexible model of consumer country-of-origin perceptions. International Marketing Review, 2000, 17(2), 127-145, doi: 10.1108/ 02651330010322615.

37. BOSONA, Techane, GEBRESENBET, Girma. Swedish Consumers' perception of food quality and sustainability in relation to organic food production. Foods, 2018, 7(4), 54, doi: 10.3390/ foods7040054.

38. BLOEMER, Josée, BRIJS, Kris, KASPER, Hans. The CoO-ELM model. A theoretical framework for the cognitive processes underlying country of origin-effects. European Journal of Marketing, 2009, 43(1), 62-89, doi: 10.1108/03090560910923247.

39. ARNDT, Johan. Role of product-related conversations in the diffusion of a new product. Journal of Marketing Research, 1967, 4(3), 291-295, doi: $10.2307 / 3149462$.

40. ANDERSON, Eugene W. Customer satisfaction and word of mouth. Journal of Service Research, 2016, 1(1), 5-17, doi: 10.1177/ 109467059800100102.

41. CHEVALIER, Judith A., MAYZLIN, Dina. The effect of word of mouth on sales: Online book reviews. Journal of Marketing Research, 2006, 43(3), 345-354, doi: 10.1509/jmkr.43.3.345.
42. GUPTA, Pranjal, HARRIS, Judy. How e-WOM recommendations influence product consideration and quality of choice: A motivation to process information perspective. Journal of Business Research, 2010, 63(9), 1041-1049, doi: 10.1016/j. jbusres.2009.01.015.

43. LEE, Yoon-Joo. Can Asian models be effective to white American consumers in values advocacy ads? The implications of collectivistic selfconstrual as a self-motive in the context of values advocacy ads. Journal of Current Issues \& Research in Advertising, 2016, 38(1), 75-91, doi: 10.1080/10641734.2016.1233156.

44. TAM, Jackie. Customer satisfaction, service quality and perceived value: An integrative model. Journal of Marketing Management, 2004, 20(7), 897-917, doi: 10.1362/0267257041838719.

45. ZEITHAML, Valarie A. Consumer perceptions of price, quality, and value: a means-end model and synthesis of evidence. Journal of Marketing, 1988, 52(3), 2-22, doi: 10.2307/1251446.

46. HSU, Chin-Lung, LIN, Judy Chuan-Chuan. Effect of perceived value and social influences on mobile app stickiness and in-app purchase intention. Technological Forecasting \& Social Change, 2016, 108, 42-53, doi: 10.1016/j. techfore.2016.04.012.

47. EL-ADLY, Mohammed Ismail, RIYAD, Eid. An empirical study of the relationship between shopping environment, customer perceived value, satisfaction, and loyalty in the UAE malls context. Journal of Retailing and Consumer Services, 2016, 31, 217-227, doi: 10.1016/j.jretconser.2016.04.002.

48. HUIJGENS, Hennie, van DEURSEN, Arie, van SOLINGEN, Rini. The effects of perceived value and stakeholder satisfaction on software project impact. Information and Software Technology, 2017, 89, 19-36, doi: 10.1016/j.infsof.2017.04.008.

49. HAIR, Joseph F., HULT, G. Tomas M., RINGLE, Christian, SARSTEDT, Marko. A primer on partial least squares structural equation modeling (PLS-SEM). Second edition. Thousand Oaks [etc.] : SAGE cop., 2017.

50. KOONCE, Glenn L., MICHAEL, D. Kelly. Analysis of the reliability and validity of a mentor's assessment for principal internships. NCPEA Educational Review, 2014, 15(2), 33-48. Available on World Wide Web: <https://files. eric.ed.gov/fulltext/EJ1105546.pdf>. 